\title{
Using an innovative multiple regression procedure in a cancer population (Part I): detecting and probing relationships of common interacting symptoms (pain, fatigue/weakness, sleep problems) as a strategy to discover influential symptom pairs and clusters [Erratum]
}

Francoeur RB. OncoTargets Ther. 2015;8:45-56.

On page 45, Background section, line three, "diesease markers" should read "disease markers". access journal focusing on the pathological basis of all cancers, potential targets for therapy and treatment protocols employed to improve the management of cancer patients. The journal also focuses on the impact of management programs and new therapeutic agents and protocols on

patient perspectives such as quality of life, adherence and satisfaction. The manuscript management system is completely online and includes a very quick and fair peer-review system, which is all easy to use. Visit http://www.dovepress.com/testimonials.php to read real quotes from published authors. 